\title{
Assessment of non-formal sexual education strategies for adolescent girls: the case of Tanzania ${ }^{1}$
}

\author{
João Casqueira Cardoso a \\ Martha Peter Mwolo a
}

\section{Abstract}

This article proposes a critical look at the non-formal education strategies, which have been conducted mainly in Dar es Salaam, Tanzania, by four nongovernmental organizations, in order to provide sexual education to girls between the ages of 12 and 16, showing the role played by the civil society in contradicting the school conservatism. Clear trends emerged from this study to indicate that sexual risky behaviours, unintended pregnancies, and HIV transmission among adolescent girls are closely related to intentional as well as unintentional reproduction of the power relations, social meanings, moral codes, stigma and silence attached to adolescents, their sexuality and sexual health within key institutions. As a result, their sexual behaviours are hidden and ignored. As schools do not develop curricula for life, NGOs play their role by means of non-formal education.

Keywords: Adolescent girls. Sexuality education. Feminine Empowerment. Non-Government Organizations. Tanzania.

\section{Setting the field}

Adolescent health persists as an important agenda in national, regional and international forums, also in academic research in the $21^{\text {st }}$ Century (BLUM et al., 2012; PATTON et al., 2012; SAWYER et al., 2012). While health is increasingly recognized as a fundamental human right, it constitutes much more than the mere absence of diseases, and sexual health is understood as an integral aspect of health. The right of all adolescents to health is itself enshrined within international human rights provisions (for example, article 12(1) and article 2(2) of the International

\footnotetext{
a University Fernando Pessoa, Porto, Portugal.

${ }^{1}$ Research funded by the Institute of Finance Management, Dar es Salaam, Tanzania.

Recebido em: 16 ago. 2016

Aceito em: 07 fev. 2017
} 
Covenant on Economic, Social and Cultural Rights; article 24 of the International Covenant on Civil and Political Rights; and article 2(1) of the Convention of the Rights of the Child). In addition, several provisions, both at international and national levels, prohibit all forms of differential treatment based, inter alia, on gender, age, and marital status, which implies the recognition of adolescents' human rights and right to their own sexuality.

Despite this legal framework, evidence demonstrates that adolescents have poor sexual health outcomes, particularly in developing countries. Sub Saharan Africa, of which Tanzania is a part, has one of the worst profiles in this respect. While substantial gains in adolescent health have been achieved, information documented in most recent national health surveys - such as demographic and health survey, Aids indicator survey, HIV and malaria indicator survey conducted in East Africa-indicate that sexual health of adolescent girls needs special attention (UNICEF, 2011).

In Tanzania, a significant number of adolescent girls become sexually active at least by the age of 15, and most of them before 18 years old. Adolescent girls bear the largest share of sexual risk behaviour, unintended pregnancies and HIV/AIDS (MADENI et al., 2011; MBEBA et al., 2012; UNICEF, 2011; UNESCO, 2013; UNITED REPUBLIC OF TANZANIA, 2011; 2013). Data released by the Ministry of Vocational Training and Education in Tanzania shows that pregnancy incidence rate among school girls has increased in the past five years, becoming now a public concern. Strangely, the public opinion seems to consider this as a phenomenon related to disciplinary issues, underlining that schoolgirls 'badly behaved' (MABALA; COOKSEY, 2008), and practice shows that in Tanzania pregnant school-going girls have been expelled from school ${ }^{2}$.

Indeed, the increase in pregnancy rates gives two signals: first, school girls, most adolescents, are sexually active, engaging in potentially risky sexual behaviours; second, although no data indicate that pregnant girls were also found to have contracted HIV/AIDS, data showing rise in pregnancy rate suggest that girls are increasingly vulnerable to sexually transmitted diseases, including HIV/AIDS. Unintended pregnancies and HIV/AIDS are not only major health issues among school-going and unmarried adolescent girls, but also among out of school and married adolescent girls (MABALA; COOKSEY, 2008; MASATU et al., 2009).

Literature also shows that institutions play a critical role in influencing behaviours related to health in individuals and groups (GACOIN, 2010). Different actors within

Tanzania passed a law to sanction expulsion of pregnant girls from school in 2002. However, there is no data to indicate that this practice is addressed to the fullest. 
institutions construct social meanings about whether sexual activity is permitted or not, who it is permitted for, for what outcomes, how and when to become sexually active (WIGHT et al., 2012; PARKER, 2001). In turn, these social meanings are internalized by individuals and groups, including adolescents, and may influence the way they perceive their own sexuality, as well as the way they engage in actual sexual behaviours, access and use of available health information and services on the same issue. In this sense, sexuality education at school is recognized as a means to transmit knowledge, as well as to inspire values, attitudes and behaviours.

In Tanzania, the formal education system, dating back the 1960s, includes seven years of primary school, starting at the age of seven years old. Primary school participation is high, both for female and male (more than 92 per cent and 95 per cent, respectively) (UNICEF, 2013). The primary education system of Tanzania suffers from several problems, one of them being the large number of over-age students. In this context, studies show that primary school students are sexually active, both in Tanzania (TODD et al., 2004) and in other Sub-Saharan Africa countries (KLEPP et al., 1994; KAAYA et al., 2002). However, sexuality is a fairly recent issue at school in Tanzania. It was only under the pressure of health policies against HIV/AIDS spreading that the sexuality started to be included in primary school programs, in the first years of the $21^{\text {st }}$ century. Sexuality was supposed to be approached in the various syllabi of the most diverse subjects, rather than taught as an autonomous subject (MKUMBO, 2009). Even though sexuality is now referred in the curricula, namely in Social Science and in Science, it is actually seldom taught. A recent study on the effectiveness of sexuality education in school curricula in Tanzania (BILINGA; MABULA, 2014) shed some light on this issue. It shows that for the primary school children, in Tanzania, the source of sexuality education is not mainly school (less than one third of the respondents see the school an educator in this field), but rather other sources (parents, media, peers and relatives).

Indeed, school tends to be conservative, as society shapes it to maintain the status quo (DURKHEIM, 1977). Reproduction theories have developed this perspective on schooling roles to maintain the social order (BOURDIEU; PASSERON, 1990). If public institutions provide weak responses to significant problems, they open the doors to other alternatives. As a result, in the Tanzanian case, pressures on school to refuse the effective inclusion of sensitive issues to curricula have opened new avenues for national and international NGOs to develop non-formal education programs ${ }^{3}$, since they enjoy much more flexibility than formal education.

\footnotetext{
3 The non-formal education concept was established in the 1970s for reaching the poorest among the poor for whom schooling was too structured and selective (ROGERS, 2005).
} 


\section{Methodology}

This research project was conducted in Tanzania, mainly in Dar es Salaam, with four selected NGOs. Both qualitative and quantitative data were collected for triangulation: quantitative data were collected for the sake of enriching the study and make data analysis more transparent, avoiding inferences and generalization of the findings. More specifically, data collected consisted in three elements:

- Thirty-three questionnaires surveys were sent to NGOs in the area of education and health, in Tanzania;

- Fourteen semi-structured interviews were conducted with education and health professionals, randomly selected on the basis of their experience in senior management positions, and their practice in civil society organizations in the area of adolescent sexual and reproductive health;

- Data gathered by means of questionnaire surveys and interviews were complemented by observation and documentary review.

The SPSS software version 22 was used to organize questionnaires analysis, and qualitative content analysis was used as a method for data analysis. Anthony Giddens (1984) structuration theory was adopted as overarching framework for analysis. It was combined with the functionalist perspective (PARSONS, 1964). This "methodological blend" is seen as an optimal choice for research in complex environments as is the African one, mixing traditional and modern settings. As demonstrated by Giddens in his structuration theory, a social phenomenon cannot be understood and addressed by focusing only on micro factors (individual aspects, or "internal" ones), but also macro factors (beyond individual, or "external" ones) (GIDDENS, 1984; GAUNTLETT, 2002). However, macro explanations are also not sufficient in themselves. The assessment of tools used by institutions with educational functions is essential here. Among the tools used by institutions, empowerment represents a significant one, enabling an individual to protect her or his own health by addressing individual level factors related to health threats. It also helps individuals to challenge or transform the factors within the broader society, particularly the social meanings of gender and adolescent sexuality that inhibit the girls' ability to avoid sexual risk behaviours.

More concretely, and in the context of Tanzania, NGOs have used five non-formal sexual education strategies, and this division will serve as a guide to divide the analysis. First, behavioural change and communication; second, voluntary counselling; third, life skills training; fourth, peer education. Last, rights based 
initiatives are used by NGOs to achieve their objectives. Each strategy may be combined with another or with several other ones.

\section{Behaviour Change and Communication}

In Tanzania, the behavioural approach has dominated educational programs on sexual health among various segments of the population, including adolescent girls. Technical and financial resources have been invested for implementing Behavioural Change and Communication (abbreviated BCC) educational programs, that enhance knowledge and attitudes related to health, aiming at delaying the age in sexual debut, at decreasing the number of sexual partners, and at increasing the use of condom. Three educational programs have been used by NGOs and follow the BCC line: ABC, MKV, and Linda Maisha yako.

First, $\mathrm{ABC}$ : This program (meaning "Abstain, Be faithful, use Condoms", or $\mathrm{ABC}$ ) includes a set of interventions combining the three implied strategies: abstinence, faithfulness between sexual partners, and the generalization of condom use. Plummer (2012), commenting on this program, notes that ABC programs have a potential for reducing sexual risk behaviour among individuals who have different priorities and desires, which includes adolescent girls. $\mathrm{ABC}$ reveals to be an overarching approach in intervention for empowering adolescents, including girls to avoid health threats in almost all non-governmental organizations.

Second, MKV: From the sentence "Mema kwa vijana" (meaning in Swahili "good things for young people"), MKV is an example of adolescent sexual health program which design was based on the ABC model. MKV was conceived, implemented and evaluated in Mwanza, in the North of Tanzania, between 1996 and 2008, in three stages: stage 1 (1996-2001), consisting in the development and evaluation; stage 2 (2001-2007), dealing with scaling up and assessment of lessons learnt; finally, stage 3 (2007-2008), including further survey for long term impact. One NGO (NGO4) spearheaded the implementation of $\mathrm{MKV}$, together with other national and international partners. The overall aim of the project was to improve sexual health of adolescents in the Mwanza region and beyond. MKV was first idealized as a school-based intervention whose primary target group was $12-17$ years old teens in the three final years of primary school education (standards 5, 6 and 7) (OBASSI et al., 2006). Drawing from the social cognitive theories (WIGHT et al., 2012), the specific objective of the project was to delay sexual activity, to decrease sexual risk behaviours and to increase uptake of appropriate health services (OBASSI et al., 2006; PLUMMER, 2012). 
Third, Linda Maisha yako: In NGO1 we had access to a booklet containing health information meant to be used by girls (trainees) and facilitators (trainers), published in 2013. The booklet was produced as part of a girl power project called 'linda Maisha yako' (meaning in Swahili "Protect your life"). The booklet contained various topics which were covered in eight topics: "sisi ni wasichana" "We are girls"), "balehe" (Puberty), "ukatili dhidi ya wanawake" ("Violence against women"), "tuzungumze kuhusu ngono" ("Let's talk about sex"), "uhusiano bora" ("Good relationship"), "kujiweka salama I \& II" ("Self-protection" I and II), and "baada ya yote haya" ("Concluding module"). There was no specification on what was the approach addressed within a particular module, but it was clear from the contents that abstinence, faithfulness and condom use were addressed within the topic "Let's talk about sex", "Self-protection I" and "Self-protection II".

A key finding emerging from the documents is that abstinence is favoured, in terms of information provided to young people. Condom use is also actively promoted for sexually active adolescents, but there is a preference for abstinence. This contrasts with the $\mathrm{ABC}$ program, where information is communicated without specifying which method is better than other (PLUMMER, 2012). The latter was relevant in most NGOs. According to the data that we have collected, abstinence messages were communicated by NGOs predominantly in late 1990s and early 2000s. Strikingly, findings also reveal that abstinence or delaying sexual debut seemed to be positioned as a strategy offering ultimate protection against unintended pregnancies and HIV/AIDS among girls. It is probably suggested as a standard norm or an indicator of good or constructive relationships. As it states: [the] majority of young people are not sexually active... but they do not look awkward, lonely or miserable... they are rather happy and satisfied" (NGO1) "Information about abstinence is not only delivered to girls, girls are taught to practice sexual refusal skills (according to the instructors' manual), advantages of saying no to sex and how to say no to sex (NGO1).

In addition, girls themselves are shown to convey a different message reinforcing the importance of delaying sexual activity, "saying no to sex is for my life... it is my decision... my choice to wait". This is echoed in other documents whereby the message from a girl (on a picture) reads, "I am planning to wait. I don't want to become pregnant before I finish school" (NGO1). At the same time, condom use is promoted as an important health protective method. For example, adolescent girls were informed that "if the penis does not have condom it should not be allowed to penetrate the vagina" (NGO3). Condom use was emphasized as an HIV/AIDS prevention method - but in case one fails to abstain or delay sexual activity, it warns that "AIDS kills smart and talented young people because they 
did not abstain from sex. If you abstain you are protected, but if you cannot abstain play it safe. Use condoms" (NGO1).

Findings also suggest that being faithful among partners is communicated to adolescents and youth, probably without much depth (PLUMMER, 2012), and/or not overtly because doing so may imply that NGOs are promoting sexual activity among adolescents, particularly unmarried ones. For example, information from a mobile placard demonstrated that the target group for 'one love' are couples. But, information in an $\mathrm{ABC}$ up to $\mathrm{Z}$ leaflet revealed that one love campaign also targeted adolescents and youth. In the leaflet the letter " $\mathrm{m}$ " stands for "Mapenzi [...]", and is quiet explicit: "Mapenzi salama; mmoja tu anatosha, mlinde, mheshimu, mhusishe" (in Swahili: "safe sex; one love is enough, protect him/her, respect him/her, involve him or her").

\section{Voluntary Counselling and Testing}

Voluntary Counselling and Voluntary HIV/AIDS testing service (also known as Voluntary Counselling and Testing, or VCT) is promoted as a sexual health prevention tool for adolescents, including girls, whereby provision of counselling, testing and related support services is understood to lead to change in sexual behaviour, particularly the reduction of the number of sexual partners.

NGO3 has operated a National Health AIDS Helpline (177) since 2001, whereby behaviour counselling and referral services, including VCT, are provided to approximately between 700 to 1,000 callers per day. There is no clear-cut gender and age-disaggregated data about VCT related calls, however. Overall, while 34\% of callers were female, $66 \%$ were males, and $78 \%$ of all callers $14-24$ years of age. Moreover, $17 \%$ of the callers were seeking information about counselling and testing, 44\% called to receive HIV/AIDS preventive counselling. NGO3 also has a mobile unit, which offers VCT services in public gatherings, such as market places, festivals and other social gatherings. They also offer what is described as "preventive counselling", which is much more than VCT services. Consistent use of Antiretroviral and treatment is described as a HIV preventive strategy. Generally, in Tanzania, NGOs have been in the frontline offering voluntary counselling and testing services. For example, NGO1 is among the first non-governmental institutions to manage and offer professional and reliable HIV counselling and testing services through its "Brighten" and "Brighten up More" interventions which constitute VCT clinics operating in almost 18 regions in Tanzania (also indicated by NGO4). 


\section{Life skills training}

Adolescent girls also need skills, so that they can be empowered to avoid sexual health threats. According to information collected from interviews and documents consulted, we identified the skills used in NGOs programs, including cartoons in magazines labelled as "No Joke," which are part of health information projects: self-esteem and awareness, effective communication (especially how to say "no" to sex proposals, unprotected sex, and peer pressure), decision-making skills, critical thinking, coping with stress, emotions and assertion to remain healthy. One participant interviewed admitted that adolescent girls live in a society expecting them to be "submissive". Lack of self-awareness among girls was echoed by another participant who said that "most girls are not empowered... they are socialized to be submissive." Thus, life skills such as self-awareness and decision-making were described to be a priority for them. It is important to underline that in most NGOs life skills were not used as a single strategy, but rather implemented together with other strategies.

\section{Peer Education}

Although there is little evidence to confirm the effectiveness of peer led education in reducing sexual risk behaviour, unintended pregnancies and HIV/AIDS prevention, it is implemented by most of the NGOs to address sexual health threats for adolescents, including girls. However, peer education is not implemented as a separate intervention, but as one of the elements in most intervention programs. In NGO3, data revealed that in 2008-2010 a total of 1,035 young people were trained as peer educators under the youth "Ambassador" intervention. Under MKV intervention two hundred and forty-eight (248) class peer educators were trained. Peer education was an integral aspect of many intervention programs. One project officer described that he and his colleagues were amazed by the impact of peer educators done by both female and males, especially for their ability to convey sexuality and sexual information to their peers in a correct form and in a way which can be easily understood, as demonstrated during meetings in clubs for out of school youth.

Some interesting results emerged from practical aspects of adolescent sexual health, in most NGOs. ABC is perceived as not exhaustive for adolescents and youths, as it does not reflect the contextual and complex reality of social relationships, love and sexuality. Therefore, there is an attempt is most other NGOs to "go beyond ABC", or "going from $\mathrm{ABC}$ to Z" as they put it. This is being implemented or adopted by most organizations, and this includes the way 
practices such as masturbation, delay of sexual debut, condom use, kissing and caressing are communicated as safe sexual behaviours to adolescents and youths.

The key message of "ABC up to Z" is that adolescents and youths have no reason to rush into having sexual intercourse, because they can find various other ways of fulfilling sexual desire, and many reasons for them not to do so. For example, some of the messages that as transmitted refer: "D-Kissing", "Do other different things together", "Have life goals", "One safe lover", "Masturbation", "Sex is dangerous", "buddy", "Masturbation?", "Settle", "It's not shameful not to have a sexual partner", "They have peace, they have tested", and "Give birth when you are ready."

\section{Human rights education strategies}

The set of NGOs studied also use Human rights education tools in order to achieve empowerment of girls as regards their sexual health. The diversity of services is worth commenting, as we find a full range of activities, from information services on reproductive rights to legal rights advocacy.

\subsection{First: Reproductive health information and services}

Overall, the majority of actors believe that when adolescent girls engage in sexual risk behaviours, they get unintended pregnancy and contract HIV/AIDS because they have limited comprehension on sexual health information. As a result, a number of activities are implemented to provide adolescents and youths with sexual health related information. "Edutainment" is the most popular tool in this field. It combines entertainment and education, including activities such as sports, theatre art, and "bongo flava" music 4 . Information obtained from NGO 4 indicated that between 2012 and 2013 four "edutainment" events were implemented in Iringa (in the centre of Tanzania) and in Dar es Salaam. As a result, it reached a total of 11,937 individuals, $48.9 \%$ of them male and $51.9 \%$ female. Out of these, around $45 \%$ aged $10-24$ years, and more than $95 \%$ aged $15-24$. "Edutainment" is also found to be at the heart of sexual rights related interventions in NGO 1. It uses multimedia communication to implement intervention related to sexual rights among youth. Different multimedia produces magazines, TV talk shows, and interactive websites. Radio and social media are used to advance sexual rights agenda for youth, including girls. Some of these are employed as part of a health information project aiming at changing risky sexual behaviours and attitudes by encouraging young people to adopt a "healthy lifestyle." A recent report indicated

4 "Bongo flava" is a local Swahili music style which is very popular. Local "bongo flava" musicians were involved in implementation of community outreach activities and events. 
that in 2006-2012 a total of 2.8 million people read "Fema" magazine (which originated from school clubs created by schools students and their teachers), and approximately 8.9 million people are familiar with this type of magazine. Further reports show that "Fema" is distributed to 2,436 schools, meaning that around 40 per cent of schools have access to them, whereas 550 schools are on the waiting list. Moreover, 1.2 million people read "Si mchezo" Si mchezo" ("No joke" magazines, targeting school youth), and 5.4 million are familiar with the referred magazines, which is distributed to almost 600 partners.

\subsection{Second: Education on sexuality}

Access at appropriate age to balanced, cultural sensitive and on-going sexuality education is fundamental for adolescents to exercise their rights to gain high standards in health (BERNE; HUBERMAN, 1999). Accordingly, reports indicate that many governments in Eastern and Southern Africa are committed to scale up comprehensive sexuality education, and so do civil society organizations. For example, a sexuality education curriculum was developed by a NGO, addressing pertinent issues related to sexuality education. The same NGO provided a sexuality education course to health care providers. Apart from that, another participant described that they are often invited to teach about sexuality in schools because they are "trusted." However, there were limitations about which sexuality issues should be communicated and how some behaviours may be imposed by some parents, teachers and government official views. So, even if providers aimed to be open-minded and non-judgmental about sex and sexuality in relation to adolescents and youths, they could not do so in practice. Instead, they tend to address sex and sexuality related issues indirectly, and cautiously, so that they are not blamed for promoting sexual activity. As one of them put it succinctly, "in our society we do not expect them (especially adolescent girls) to be sexually active... it is difficult to do away with that."

Condom education is considered as an important aspect of sexuality education. Its use promotion and distribution is found to be the core aspect of most of the intervention programs. According to data from a baseline survey conducted by NGO 1 in 2010, few adolescents and youths asked for condoms, less that $20 \%$ (out of 87/462) who visited the health facility within the period of three to twelve months. Nevertheless, many participants explained that more often than not, during community outreach programs, onsite clinics, and edutainment (called "bonanza"), they run out of condoms and had to go back to their premises to fetch for more. Yet, another data seems to confirm the lack of behaviour patterns, as during another four-community outreach "bonanza", conducted between June 2012 and May 2013, condom distribution corresponded only to $19 \%$ (out of 11,937 ) youths. 


\subsection{Third: Family planning services}

Access to family planning and contraceptives is a right for adolescent girls and is important for reducing unintended pregnancies (PRESLER-MARSHALL; JONES, 2012). Results show that almost all the NGOs provide adolescents with contraceptive knowledge and information, counselling and service either directly or through referrals. However, most program managers said that it was hard to implement activities aiming to provide access to family planning service, and especially to girls. Provision of contraceptive information and services to adolescents, in particular female, is generally controversial. Simultaneously, girls receive information from some religious institutions that using modern family planning methods is a sin, similar to killing. During implementation of family planning promotion activities, teachers and government officials often remind NGOs' practitioners that girls should not be taught, since they are children.

Data also indicate that many NGO practitioners are aware that in Tanzanian societies girls are not expected to use modern family planning methods (MBEBA et al., 2012). If a girl is found with a condom, a contraceptive pill or any modern contraceptive method within school compound, this can be a reason for punishment or even expulsion from school. Yet, NGOs do it anyway. As observed from an extract in a booklet: "There are various pregnancy prevention methods relevant to youth: abstinence; pills; male and female condoms; spermicidal foams; emergency contraceptives. Among these abstinence is the best [...]". It is interesting to note from the above quote that, although information about use of modern contraceptives for pregnancy prevention is communicated to adolescents, despite social restrictions, abstinence is suggested as the most favourable pregnancy prevention method, reflecting an "official" doctrine on the issue (both influenced by the government and by the religious authorities).

\subsection{Fourth: Safe motherhood services and the issue of abortion}

The performance of abortion is generally prohibited in Tanzania, and criminally sanctioned under the Revised Penal Code of Tanzania (sections 150 to 152). However, provision of post-abortion care services is allowed. Therefore, some NGOs use referral; others, such as NGO 2 in this case, offer direct post-abortion care services, as well as vocational skills, family planning and counselling services to teenage mothers. This organization aims to enable teenage mothers to protect their health and become economically independent. Integrated abortion and safe motherhood services are offered in clinics operated by NGO 2, located all over the country, especially at Temeke Centre in Dar es Salaam. 


\subsection{Fifth: Youth Friendly Health Services}

Adolescents need sexual health services tailored to meet their needs and rights. Accordingly, World Health Organization (WHO) advocates for provision of adolescent or youth friendly services to all adolescents (KRUG et al., 2002). Adolescent friendly health services are considered important for removing barriers in accessing health services and information and for improving health among adolescents. According to the WHO, adolescent friendly services must be accessible, equitable, acceptable, appropriate, comprehensive, effective and efficient, and mostly important, they should be delivered in a friendly and non-judgmental manner (CHANDRA-MOULI et al., 2013). Research results indicate that three strategies are used. First, NGOs provide direct youth friendly services through model youth centres, on site, and use normal clinics. One NGO has clinics offering reproductive services, located in many regions. Second, NGOs also act by providing referrals. Third, NGOs contribute to build competencies of healthcare workers to deliver youth friendly services, and help to build health centres where they are not available at all. This is done according to the needs they find within the targeted areas. As one senior manager emphasized:

\section{"When girls come to our clinics, we give them all the information and services they need, and answer all their questions." As another one put it, "when we implement our interventions we do not say only married, sexually active adolescents, or those who are not sexually active or boys... are eligible to have access to our products."}

\subsection{Sixth: Sexual health rights advocacy}

As far as advocacy for sexual health is concerned, results reveal that most NGOs promote awareness about sexual health threats facing adolescents and youths. They promote awareness to these groups themselves, social gatekeepers, and communities that adolescents and youth have right to sexual and reproductive health information and services. Simultaneously, they advocate for policy and budget allocation to ensure that sexual and reproductive health rights of adolescents and youth are respected. At the time the researcher was in the field, two NGOs supported a review of the national policy guidelines. As a participant elucidated, national health policy needs to be reviewed, since it does not address adolescent sexual and reproductive health as a right. For instance, a restriction to the distribution of condoms and contraceptives at schools is a violation of their rights, because most of them are sexually active. Besides that, the Marriage Act allows girls to be married at the age of 15 as long as their parents consent. This, if generalized as it is, clearly undermines their right to education, at the same time that it subjects them to various maternal health problems, and even to death. 
Arguably, human rights or rights based approach is more promising and potential in empowering adolescent girls to avoid risky sexual behaviours, unintended pregnancies and HIV/AIDS compared to other conventional approaches. Human rights or right based approach challenges the social meanings attached to feminine identity and adolescent girls' sexuality, as well as other elements such as traditions, religious beliefs, age, marital status and school status which jeopardize sexual health of adolescent girls, and for rendering them potential victims of female genital cutting or mutilation, coerced or forced sexual activity, and early marriage.

\section{Conclusions}

This study found mixed results about the civil society actors' perceptions in relation to what the best strategies to avoid risky sexual behaviours among adolescent girls in Tanzania actually are. Most NGO actors are aware of the actual sexual behaviours of adolescent girls and they do not perceive girls to be asexual. On the opposite, a majority of participants perceive adolescent girls to be sexually active just like adolescent boys of similar age. But there was also a minority of participants who demonstrated denial and negative perceptions about girls' sexuality.

Similar to providers in healthcare institutions, some NGO actors have negative perceptions and restrictive views about adolescent sexuality, reflected by messages like "sexual intercourse is something special that nobody should decide for you... but it is important to wait until we ready age wise... and most important in marriage." Other NGO send conflicting messages, such as "to start menstruation is itself not a permission to begin to have sexual intercourse" and "experiencing first menstruation signifies that a girl has entered adulthood." These messages in societies which have not undergone sexual revolution, such as Tanzania, reinforce the view that girls should not be sexually active until they are adults, i.e. until they finish school, and mostly important when they actually marry.

The design and implementation of sexual health education programs is, in our view, influenced by a "new" norm of "appropriate sexual behaviours" for girls, which somehow deviated from the mainstream view of adolescent girls' sexuality in Tanzanian society. While the standard norm for adolescents, especially girls, is to abstain from sex until marriage, in adolescent sexual health education practice in NGOs, sexual activity is deemed appropriate when girls are matured and/or are in stable or romantic relationship. Consequently, alternative ways of fulfilling sexual desire such as kissing, touching, and masturbation are communicated to girls, but issues such condom use and other ways of contraception are still indirectly looked at. 
Empirical data demonstrated that NGOs in Tanzania have taken on roles that are performed by governments in most developed countries. This may be also the case in a more global African context. NGOs have initiated and implemented several intervention educational programs aiming at promoting sexual health of adolescents, including girls: ABC, voluntary counselling and testing, life skills development, peer education, biomedical intervention, provision of sexuality education, provision of family planning, provision of post-abortion care, youth and adolescent friendly service; advocacy for policy change; economic empowerment and civic engagement; prevention of gender-based violence and male involvement. The present study did not find an intervention program that explicitly, and specifically, targeted to transform the social meanings about acceptable and unacceptable gender and adolescent sexuality and other elements such as traditions, religious beliefs, age, marital status and school status. Despite good intentions, the capability of NGOs to make a difference and to influence this state of affairs may be inefficient and short lived.

Empirical data did not demonstrate that focused NGOs do not address the factors in the broader society related to sexual health among adolescents and youths, including girls. Intervention programs are meant to empower adolescents, but only a few empower girls economically. Economic empowerment, especially through provision of access to entrepreneurial training, capital and microcredit, was perceived as an important health protection strategy as life skills training and development. The rationale behind these intervention programs is that poverty has significant influence on risky sexual behaviours, unintended pregnancies, and HIV/AIDS. Even though it cannot be affirmed that the poor is more sexual risky in all societies (DJAMBA; KIMAMU, 2008), poverty is often linked with other factors (MABALA; COOKSEY, 2008) that constitute effective risks for health. Yet, most NGOs educational intervention programs were more gender sensitive than transformative.

Most NGOs in Tanzania greatly depend on external funding sources. As a consequence, decisions about nature and type of intervention programs implemented to empower adolescent girls to avoid sexual risk behaviours, unintended pregnancies, and HIV/AIDS may somehow have been influenced by the agenda and priorities of donors and donor institutions. Part of donors and donor organization are seldom prone to finance long term programs, especially those that would address gender at the level of the society. The life span of most of the interventions varied between two and four years, which is already a limit to a sustainable educational program. 
Some donor institutions have their own agenda about what intervention work as far as preventing risky sexual behaviours, unintended pregnancies, and HIV/AIDS among adolescent girls is concerned. Most interventions that were financed by donor and donor institutions from the United States of America aimed behavioural change and communication, biomedical, and conventional public health approaches in adolescent sexual and reproductive health. In contrast, intervention programs financed by European donors and donor institutions focused on promoting health life style through bombarding youth with health related information and provision of youth friendly services. Most of them had a right based dimension, somehow too formalistic to be efficient. In most of the developed countries, especially in Europe, adolescents, including girls, are considered as rational individuals whose sexual health-related rights need to be respected and protected through provision of comprehensive sexuality information and services. Adolescents are expected to behave responsibly in relation to their sexuality, but this is not the case for many of them.

Most NGOs adopt a principle of "neutrality" in sexual health related to educational intervention programs, meaning that these organizations do not interfere on the culture of the society in which they operate. However, this is achieved perhaps more in theory than in practice. In fact, adhering to the principle of neutrality may reinforce discrimination of certain individual and groups, in this case adolescent girls, and make their sexual health needs and situation go underground.

It is finally observed that in the Tanzanian society, most educational intervention programs on the subject of condoms and other family planning face public policy restrictions. Consequently, these restrictions affect daily the implementation of activities and overall efficiency of NGOs. In fact, the country has no stand formal sexuality education. Worse than that, sexuality related information and materials provided by NGOs were censored in the past. NGO actors were not allowed to have open communication about sex and sexuality. Therefore, they resort to beat about the bushes when delivering sexuality related information to adolescent girls. Condoms used for promotion in educational activities were also restricted by some teachers and religious leaders. Moreover, most education program managers reported that implementing activities aiming at providing access to family planning service to adolescents was an uphill task. Provision of contraceptive information and services to adolescents, especially schoolgirls, is still generally controversial.

One of our main conclusions is that NGOs should not reinforce the identified collective views about acceptable and unacceptable feminine identity and 
adolescent girls' sexuality and other elements, such as traditions, religious beliefs, age, marital status and school status. This requires continuous and critical reflection on actions related to adolescent girls' sexuality. Most of the educational interventions drew from several behavioural, socio-psychological and sexual rights perspectives. But the core challenge is to help the society to transform, and more interventions should target to change the identified social meanings attached to feminine identity and adolescent girls' sexuality. 


\section{Avaliação das estratégias de educação sexual não formal para as meninas adolescentes: o caso da Tanzânia}

\section{Resumo}

Este artigo propõe uma visão crítica das estratégias educacionais não formais levadas a efeito sobretudo em Dar es Salaam, Tanzânia, por quatro organizações não governamentais, a fim de prover a educação em sexualidade junto de meninas de 12-16 anos e sublinhando o papel da sociedade civil em mudar o conservadorismo das escolas. $O$ estudo revelou tendências de que tais comportamentos e fatos estão estreitamente relacionados à reprodução intencional ou não a relações de poder, significados sociais, códigos morais, estigmas e silêncio sobre a sexualidade e a saúde sexual das meninas adolescentes por parte de instituições-chave. Assim, os comportamentos sexuais delas são ocultados e ignorados. Como as escolas se recusam a desenvolver currículos para a vida, as ONGs ocupam seu lugar com a educação não formal.

Palavras-chave: Meninas adolescentes. Educação em sexualidade. Empoderamento feminino. Organizações Não Governamentais. Tanzânia.

\section{Evaluación de las estrategias de educación sexual no formal para las niñas adolescentes: el caso de Tanzania}

\section{Resumen}

Este artículo propone uma visión crítica de las estrategias educativas no formales usadas por cuatro organizaciones no gubernamentales en Dar es Salaam, Tanzania, con niñas de 12 a 16 años, mostrando el papel desarrollado por la sociedad civil para cambiar el conservadurismo de la escuela. El estudio reveló que tales comportamientos, embarazos y transmisión de HIVVIH están estrechamente relacionados a la reproducción intencional, o no, por instituciones clave, de relaciones de poder, significaciones sociales, códigos morales, estigmas y al silencio que cubre la sexualidad así como la salud sexual de las niñas. Como consecuencia, sus conductas sexuales son ocultadas y ignorados. Como las escuelas no desarrollan planes de estudios para la vida, as ONGs actúan pora través de la educación no formal.

Palabras clave: Niñas adolescentes. Educación en sexualidad. Empoderamiento femenino. Organizaciones No Gubernamentales. Tanzania. 


\section{References}

BERNE, L.; HUBERMAN, B. European approaches to adolescent sexual behaviour and responsibility: executive summary and call to action. Washington, DC; Advocates for Youth, 1999.

BILINGA, M.; MABULA, N. Teaching sexuality education in primary schools in Tanzania: challenges and implications. Journal of Education and Practice, v. 5, n. 27, p. 21-30, 2014.

BLUM, R. W. et al. Adolescent health in the 21st Century. Lancet, v. 379, n. 9826 , p. 1567-8, Apr. 2012. https://doi.org/10.1016/S0140-6736(12)60407-3

BOURDIEU, P.; PASSERON, J.-C. Reproduction in education, society and culture. 2. ed. London: Sage, 1990.

CHANDRA-MOULI, V.; BALTAG, V.; OGBASELASSIE, L. Strategies to sustain and scale up youth friendly health services in the Republic of Moldova. BMC Public Health, v. 13, n. 1, p. 284-8, 2013. https://doi.org/10.1186/1471-2458-13-284

DJAMBA, Y.K.; KIMAMU, R.S. Poverty and premarital sex in comparative perspective, In: ANNUAL MEETING PROGRAM, 2008, New Orleans. Silver Sprin: Population Association of America, 2008. Available from: $<$ http://paa2008.princeton.edu/papers/80126>. Acess in: 16 ago. 2016.

DURKHEIM, E. The evolution of educational thought: lectures on the formation and development of secondary education in France. London: Routledge and Kegan Paul, 1977.

GACOIN, A. Sexuality, gendered identities and exclusion: the deployment of proper (hetero) sexuality within an HIV-prevention text from South Africa. Culture, Health \& Sexuality, v. 12, n. 4, p. 429-44, May 2010. https://doi.org/10.1080/13691051003602596

GAUNTLETT, D. Media, gender and identity: an introduction. Routledge: London, 2002.

GIDDENS, A. The constitution of society, an outline of structuration theory. Berkeley: University of California Press, 1984.

KAAYA, S. et al. School-based sexual health interventions in sub-Saharan Africa: a review. Social Dynamics, v. 28, n. 1, p. 64-88, May 2002. https://doi.org/10.1080/02533950208458723 
KLEPP, K. et al. AIDS education for primary school children in Tanzania: an evaluation study. $A I D S$, v. 8, n. 8, p. 1157-62, 1994.

KRUG, E. G. et al. World report on violence and health. Geneva: WHO, 2002. Available from: $<$ http://www.who.int/violence_injury_prevention/violence/ world_report/en/>. Acess in: 13 ago. 2016.

MABALA, R.; COOKSEY, B. Mapping adolescent vulnerability to HIV in Dar es Salaam: results from an explorative study: draft report. Tamasha Vijana: Tanzania Development Research Group, 2008.

MADENI, F.; HORIUCHI, S.; IIDA, M. Evaluation of a reproductive health awareness program for adolescence in urban Tanzania a quasi-experimental pre-test post-test research. Reproductive Health, v. 8, p. 21-9, June 2011. https://doi.org/10.1186/1742-4755-8-21

MASATU, M. C. et al. Predictors of risky sexual behaviours among adolescents in Tanzania. AIDS and Behavior, v. 13, n. 1, p. 94-9, Feb. 2009. https://doi.org/10.1007/s10461-007-9292-x

MBEBA, R. M. et al. Barriers to sexual reproductive health services and rights among young people in Mtwara district, Tanzania: a qualitative study. The Pan African Medical Journal, v. 13, Suppl 1, p. 13-8, Dec. 2012.

MKUMBO, K. A. Content analysis of the status and place of sexuality education in the national school policy and curriculum in Tanzania. Educational Research and Review, v. 4, n. 12, p. 616-25, Dec. 2009.

OBASSI, A. I. et al. Rationale and design of the MEMA kwaVijana adolescent sexual and reproductive health intervention in Mwanza Region, Tanzania. AIDS Care, v. 18, n. 4, p. 311-22, May 2006. https://doi.org/10.1080/09540120500161983

PARKER, R. Sexuality, culture, and power in HIV/AIDS research. Annual Review of Anthropology, v. 30, p. 163-79, Oct. 2001. https://doi.org/10.1146/annurev.anthro.30.1.163

PARSONS, T. The social system. New York: The Free Press of Glencoe, 1964.

PATTON, G. C. et al. Health of the world's adolescents: a synthesis of internationally comparable data. The Lancet, v. 379, n. 9826, p. 1665-75, Apr. 2012. https://doi.org/10.1016/S0140-6736(12)60203-7 
PLUMMER, M. L. Promoting abstinence, being faithful, and condom use with young Africans: qualitative findings from an intervention trial in rural Tanzania. New York: Lexington Books, 2012.

PRESLER-MARSHALL, E.; JONES, N. Charting the future: empowering girls to prevent early pregnancy. London: Overseas Development Institute, 2012.

ROGERS, A. Non-formal education: flexible schooling or participatory education? New York: Springer, 2005.

SAWYER, S. M. et al. Adolescence: a foundation for future health. Lancet, v. 379, n. 9826, p. 1630-40, Apr. 2012. https://doi.org/10.1016/S0140-6736(12)60072-5

TODD, J. et al. The sexual health of pupils in years 4 to 6 of primary schools in rural Tanzania. Sexually Transmitted Infections, v. 80, n. 1, p. 35-42, Feb. 2004. https://doi.org/10.1136/sti.2003.005413

UNICEF. Adolescence in Tanzania. Dar es Sallam: Unicef Tanzania, 2011. Available from: $<\mathrm{http}: / / \mathrm{www}$.unicef.org/tanzania/Tanzania_adolescents_for_ young_people.pdf $>$. Acess in: 16 ago. 2016.

. Tanzania, United Republic of: Statistics. Paris, 2013. Available from: $<$ https://www.unicef.org/infobycountry/tanzania_statistics.html $>$. Acess in: 11 jan 2017.

UNITED NATIONS EDUCATIONAL, CIENTIFIC AND CULTURE ORGANIZATION - Unesco . Young people today, time to act now: why adolescents and young people need comprehensive sexuality and sexual and reproductive health services in Eastern and Southern Africa. Paris, 2013. Available from: $<$ http:// unesdoc.unesco.org/images/0022/002234/223447E.pdf > . Acess in: 16 ago. 2016.

UNITED REPUBLIC OF TANZANIA. National Bureau of Statistics. Tanzania demographic and health survey 2010. Dar es Salaam, 2011.

. National Bureau of Statistics. Tanzania HIV/AIDS and Malaria Indicator Survey 2011-12. Dar es Salaam: Tanzania Commission for AIDS, 2013.

WIGHT, D.; PLUMMER, M.; ROSS, D. The need to promote behaviour change at the cultural level: one factor explaining the limited impact of the MEMA kwa Vijana adolescent sexual health intervention in rural Tanzania: a process evaluation. BMC Public Health, v. 12, n. 1, p. 788-99, Sep. 2012. https://doi.org/10.1186/1471-2458-12-788 


\section{(c) $\underset{\mathrm{BY}}{\mathrm{P}} \mathrm{NC}$}

\section{Informações dos autores}

João Casqueira Cardoso: Associate Professor, University Fernando Pessoa, Porto, Portugal. Contato: jcasq@ufp.edu.pt

Martha Peter Mwolo: Researcher, University Fernando Pessoa, Porto, Portugal. Contato: mmwolo@yahoo.co.uk 